\title{
PENGARUH KEADILAN PROSEDURAL TERHADAP PENGANGGARAN PARTISIPATIF MELALUI KOMITMEN ORGANISASI
}

\author{
Andry Arifian Rachman \\ Fakultas Ekonomi Universitas Bandung \\ an25dry@yahoo.com
}

\begin{abstract}
This study aims to examine: (1) the influence of procedural fairness to participative budgeting; and (2) the influence of procedural fairness to participative budgeting through organization commitment.The purpose of descriptive research method used in this study is to obtain a description of the characteristics of the variables and then verification is applied to determine the relationships between variables through hypothesis testing. The population in this research is 165 officers in 55 Local Government Unit Agencies (SKPDs) in West Java Province. Validity and reliability of questionnaires are tested before examining the hypotheses. Structural Equation Modeling (SEM) is used as the analysis technique in this research.The research findings are as follows: (1) procedural fairness hasa positive effect on the participative budgeting; and (2) procedural fairness has a positive effect on the participative budgeting through organization commitment.
\end{abstract}

Keywords:procedural fairness, organizational commitment, participative budgeting

\section{PENDAHULUAN}

Anggaran merupakan alat bagi manajemen dalam menjalankan fungsi perencanaan dan pengendalian. Manajemen menjadikan anggaran sebagai pedoman kerja untuk jangka waktu tertentu dan sebagai alat untuk mengukur keberhasilan/ketidakberhasilan organisasi di dalam mencapai target anggaran. Perilaku manusia mempunyai peranan penting dalam proses penyusunan anggaran, mulai dari penetapan tujuan dan pengalokasian sumber daya yang dimiliki, pelaksanaan anggaran, sampai dengan pengawasan dan evaluasi terhadap pelaksanaan anggaran (Siegel dan Marconi1989).

Penting untuk dipahami aspek perilaku disfungsional maupun perilaku fungsional para manajer atas proses penyusunan anggaran. Perilaku disfungsional (dysfunctional behavior) sebagai efek samping penganggaran, meliputi: ketidakpercayaan (distrust), resistensi (resistance), konflik internal (internal 
conflict), maupun efek-efek samping lainnya yang tidak dikehendaki (Siegel dan Marconi1989).

Perilaku fungsional (functional behavior) yang diharapkandalam penganggaran berupa peningkatan kinerja manajer karena termotivasi oleh anggaran yang digunakan sebagai dasar penilaian kinerja mereka, karena anggaran yang telah disusun merupakan kontrak kerja tahunan yang harus dapat diwujudkan. Dengan demikian dapat dikatakan bahwa anggaran merupakan annual performance contract atau fixed performance contract bagi para manajer pelaksana di mana kinerja manajer akan diukur berdasarkan pencapaian anggaran secara efisien dan efektif (Hope dan Fraser2003; Suharman 2006).

Tabel 1

Hasil Studi Empiris Mengenai

Hubungan Penganggaran Partisipatif dengan Kinerja

\begin{tabular}{cll}
\hline No. & \multicolumn{1}{c}{ Peneliti } & Hasil Penelitian \\
\hline 1. & Bass dan Levitt (1963) & \\
2. & Cherington dan Cherington (1973) & \\
3. & Milani (1975) & \\
4. & Ivancevich (1976) & Hubungan positif signifikan \\
5. & Kenis (1979) & \\
6. & Merchant (1981) & \\
7. & Locke et al. (1984) & \\
8. & Brownell dan McInnes (1986) & \\
9. & Brownell dan Hirst (1986) & \\
10. & Chenhall dan Brownell (1988) & \\
11. & Dosset et al. (1979) & \\
12. & Latham dan Michael (1979) & \\
13. & Mia (1988) & \\
14. & Latham dan Yulk (1976) & Hubungan negatif tidak signifikan \\
15. & Latham dan Marshall (1982) & \\
16. & Stedry (1960) & \\
17. & Bryan dan Locke (1967) & \\
18. & Campbell dan Gingrich (1986) & \\
\hline \multicolumn{2}{l}{ Sumber:berbagai jurnal (diolah) } &
\end{tabular}

Berbagai penelitian telah dilakukan umumnya menguji hubungan antara partisipasi dengan kinerja (sebagai konsekuennya), dengan hasil yang bertentangan (tidak konsistensi), seperti dapat dilihat pada Tabel 1.

Dalam penelitian ini peneliti tertarik untuk meneliti lebih lanjut mengenai variabel anteseden dari penganggaran partisipatif. Shields dan Shields (1998) menyatakan bahwa penelitian itu penting tidak hanya memahami konsekuensi penganggaran partisipatif, tetapi juga untuk menginvestigasi antesedennya. Penelitian ini memilih dua faktor sebagai variabel anteseden penganggaran partisipatif yang potensial, yaitu: keadilan prosedural dan komitmen organisasi dengan alasan sebagai berikut. 
Pertama, keadilan (fairness) merupakanperan keadilan dalam proses penganggaran yang telah menjadi fokus riset dalam akuntansi keperilakuan. Libby (1999) mengakui bahwa organisasi yang bekerja dengan sumber-sumber yang terbatas tidak dapat memenuhi semua permintaan yang berkaitan dengan penganggaran. Oleh karena itu, harus ada prosedur yang adil untuk mendistribusikan sumber daya yang terbatas tersebut.

Dilihat dari sudut pandang penganggaran, keadilan prosedural merupakan persepsi bawahan atas keadilan proses yang digunakan oleh pimpinan (atasannya) untuk mengevaluasi kinerja bawahan, mengkomunikasikan umpan balik dari kinerja yang dicapai, dan menentukan penghargaan bagi bawahan (Lau dan Lim 2007 dalam Yucel dan Gunluk 2007). Pengaruh keadilan prosedural terhadap penganggaran partisipatif dapat dilihat dari meningkatnya inisiatif dan berbagi informasi antara atasan dan bawahan (Wang dan Nayir2010).

Kedua,komitmen organisasi merupakan loyalitas individu yang diberikan kepada organisasi tempat di mana individu tersebut bekerja (Porter et al., 1974 dalam Wong-On-Wing et al.,2010). Steers dalam Sopiah (2008) menyatakan bahwa komitmen organisasi dapat dilihat dari: a) kepercayaan dan penerimaan yang kuat atas tujuan dan nilai-nilai organisasi; b) kemauan untuk mengusahakan tercapainya kepentingan organisasi dan c) keinginan yang kuat untuk mempertahankan keanggotaan organisasi.

Penting bagi organisasi (baik di dalam organisasi privat maupun organisasi sektor publik), untuk memahami komitmen dari para anggota organisasinya. Clinton (1999) dalam Wong-On-Winget al. (2010) menyatakan bahwa komitmen organisasi merupakan anteseden dari penganggaran partisipatif. Hal ini diharapkan bahwa dengan adanya komitmen individu yang lebih kuat serta dengan keterlibatan mereka di dalam organisasi yang lebih tinggi maka dapat dicapai tingkat partisipasi dalam penyusunan anggaran yang lebih tinggi.

Komitmen organisasi mendorong manajer berpartisipasi dalam proses penganggaran. Kepercayaan yang kuat dari manajer terhadap dan diterimanya tujuan-tujuan dan nilai-nilai organisasi, mendorong manajer bersedia berpartisipasi dalam penyusunan anggaran. Manajer yang memiliki komitmen yang tinggi merasa memiliki organisasinya sehingga mau berpartisipasi dalam proses penyusunan anggaran. Komitmen organisasi mendorong partisipasi dalam penyusunan anggaran karena dengan partisipasi tersebut para manajer dapat mengusulkan kepada manajer atasannya mengenai usaha-usaha terbaik yang bermanfaat bagi organisasi dan dapat digunakan untuk mencapai tujuan organisasi yang dipimpinnya (Supriyono2006).

Mardiasmo (2005) menyatakan bahwa anggaran sektor publik mempunyai peranan penting:a)anggaran merupakan alat bagi pemerintah untuk mengarahkan pembangunan sosial-ekonomi, menjamin kesinambungan dan meningkatkan kualitas hidup masyarakat; b) anggaran diperlukan karena adanya masalah keterbatasan 
sumber daya (scarcity of resources), pilihan (choise) dan trade offs; serta c) anggaran diperlukan untuk meyakinkan bahwa pemerintah telah bertanggung jawab terhadap rakyat.

Mengingat pentingnya anggaran sektor publik tersebut, maka seharusnya APBD disusun berdasarkan prinsip-prinsip pokok anggaran sektor publik. Sebagai contoh, Permendagri Nomor 22 Tahun 2011 tentang Pedoman Penyusunan APBD Tahun Anggaran 2012 menyatakan bahwa dalam penyusunan APBD harus memperhatikan prinsip-prinsip: a) APBD disusun sesuai dengan kebutuhan penyelenggaraan pemerintahan daerah; b) APBD harus disusun secara tepat waktu sesuai tahapan dan jadwal; c) penyusunan APBD dilakukan secara transparan; d) penyusunan APBD harus melibatkan partisipasi masyarakat; e) APBD harus memperhatikan rasa keadilan dan kepatutan; serta f) substansi APBD dilarang bertentangan dengan kepentingan umum, peraturan yang lebih tinggi dan peraturan daerah lainnya.

\section{Keadilan Prosedural}

Berdasarkan literatur organisasional istilah yang digunakan adalah procedural justice, namun menurut Dellaportas et al. (2005) dapat pula digunakan istilah fairness. Untuk kepentingan penelitian ini maka penulis menggunakan istilah fairness. Teori tentang keadilan prosedural berhubungan dengan prosedur-prosedur yang digunakan organisasi untuk mendistribusikan hasil dan sumber daya organisasi kepada para anggotanya, sebagaimana yang dikemukakan oleh Robbins dan Judge (2008) keadilan prosedural merupakan keadilan yang dirasakan atas proses yang digunakan untuk menentukan hasil. Keadilanprosedural berhubungan dengan keadilan dan kelayakan prosedur-prosedur yang digunakan untuk mengalokasikan keputusan-keputusan dalam organisasi (Frixell 1992; Conlon 1993 dan Aquino 1999).

Kinnersley et al.(2008) menyusun kriteria atas prosedur penganggaran pemerintah yang adil, yang diadopsi dari Leventhal (1980), Greenberg (1986), Tyler (1988), Magner dan Johnson (1995), Magner et al. (2000), serta Staley dan Magner (2007) yang terdiri atas hal-hal sebagai berikut.

a. Formal Budgetary Procedures Fairness, meliputi hal-hal berikut.

Voice, adanya kesempatan yang mencukupi untuk menyuarakan pendapatpendapat aparat mengenai keputusan penganggaran yang dapat mempengaruhi program-program mereka.Appeal, adanya prosedur penganggaran yang berisi ketentuan yang memperbolehkan aparat untuk mempertimbangkan keputusan penganggaran yang dapatmempengaruhi program-program mereka.Accuracy, adanya prosedur penganggaran formal yang dapat memastikan bahwa keputusan penganggaran mempengaruhi program berdasarkan informasi yang akurat.Consistency, prosedur penganggaran formal harus dapat diterapkan secara konsisten.Ethicality, prosedur penganggaran formal harus sesuai dengan standar 
etika dan moral yang meliputi kepatuhan terhadap hukum dan peraturanperaturan.

b. Budgetary Procedures Implementation Fairness, meliputi hal-hal berikut.

Interpersonal sensitivity, adanya kepedulian, perhatian, rasa hormat yang diberikan kepada aparat pada saat menerapkan prosedur penganggaran.Consideration of opinions, memberikan pertimbangan yang sungguh-sungguh atas pendapat yang disampaikan dalam rangka penyusunan anggaran.Explanations, penjelasan yang mencukupi, jelas dan tepat waktu untuk alasan-alasan yang disampaikan pada saat mengambil keputusan mengenai penganggaran.Bias suppression, menghindari adanya bias diantara satu unit dengan unit lain pada saat menerapkan prosedur penganggaran.

\section{Komitmen Organisasi}

Komitmen organisasi yang tinggi sangat diperlukan dalam sebuah organisasi, karena terciptanya komitmen yang tinggi akan mempengaruhi situasi kerja yang profesional. Hal ini antara lain dikarenakanorganisasi membutuhkan karyawan yang memiliki komitmen organisasi yang tinggiagar organisasi dapat terus bertahan serta meningkatkan jasa dan produk yangdihasilkannya.

Mowday (1982) menyatakan bahwa komitmen organisasional merupakan dimensi perilaku penting yang dapat digunakan untuk menilai kecenderungan karyawan untuk bertahan sebagai anggota organisasi.Minner dalam Sopiah (2008) mendefinisikan komitmen organisasi sebagai sebuah sikap, memiliki ruang lingkup yang lebih global daripada kepuasan kerja, karena komitmen organisasi menggambarkan pandangan terhadap organisasi secara keseluruhan, bukan hanya aspek pekerjaan saja.

Allen dan Meyer (1990) merumuskan tiga dimensi komitmen organisasi, yaitu: affective, continuance dan normative. Ketiga hal ini lebih tepat dinyatakan sebagai komponen atau dimensi dari komitmen berorganisasi, daripada jenisjenis komitmen berorganisasi. Hal ini disebabkan hubungan anggota organisasi dengan organisasi mencerminkan perbedaan derajat ketiga dimensi tersebut.

\section{a. Affective commitment}

Komitmen afektif berkaitan dengan keterikatan emosional karyawan, identifikasi dan keterlibatan karyawan pada organisasi. Karyawan yang memiliki komitmen afektif yang kuat akan terus bekerja dalam organisasi karena mereka memang ingin (want to)melakukan hal tersebut. Dengan demikian komitmen afektif terjadi jika karyawan ingin menjadi bagian dari organisasi karena adanya ikatan emosional. 


\section{b. Continuance commitment}

Continuance commitmentberkaitan dengan an awareness of the costs associated with leaving the organization. Hal ini menunjukkan adanya pertimbangan untung rugi dalam diri karyawan berkaitan dengan keinginan untuk tetap bekerja atau justru meninggalkan organisasi. Karyawan yang bekerja berdasarkan komitmen berkelanjutan ini bertahan dalam organisasi karena mereka butuh (need to) melakukan hal tersebut karena tidak adanya pilihan lain.

Dengan demikian komitmen berkelanjutan terjadi jika karyawan tetap bertahan pada suatu organisasi karena membutuhkan gaji dan keuntungan-keuntungan lain, atau karena karyawan tersebut tidak menemukan pekerjaan lain. Anggota organisasi dengan continuance commitment yang tinggi akanterus menjadi anggota dalam organisasi karena mereka memiliki kebutuhan untuk menjadi anggota organisasi tersebut.

\section{c. Normative commitment}

Komitmen normatif berkaitan dengan perasaan wajib untuk tetap bekerja dalam organisasi. Karyawan yang memiliki komitmen normatif yang tinggi merasa bahwa mereka wajib (ought to) bertahan dalam organisasi. Dengan demikian komitmen normative terjadi karena timbulnya nilai-nilai dalam diri karyawan.Karyawan bertahan menjadi anggota organisasi karena adanya kesadaran bahwa komitmen terhadap organisasi merupakan hal yang seharusnya dilakukan.

\section{Penganggaran Partisipatif}

Brownell (1982) menyatakan, penganggaran partisipatif adalah tingkat keterlibatan danpengaruh individu dalam penyusunan anggaran, sementara Chong (2002) menyatakansebagai proses dimana bawahan/pelaksana anggaran diberikan kesempatan untukterlibat lebih dalam dan mempunyai pengaruh dalam proses penyusunan anggaran.Kesempatan yang diberikan diyakini meningkatkan pengendalian dan rasaketerlibatan dikalangan bawahan/pelaksana anggaran. Partisipasi manajer dalamproses penganggaran mengarah kepada seberapa besar tingkat keterlibatan manajerdalam menyusun anggaran serta pelaksanaannya untuk mencapai target anggaran(Kenis1979).

Partisipasi secara luas pada dasarnya merupakan proses organisasional, paraanggota organisasi terlibat dan mempunyai pengaruh dalam suatu pembuatankeputusan yang berkepentingan dengan mereka. Partisipasi dalam kontekspenyusunan anggaran merupakan proses para individu, yang kinerjanya dievaluasidan memperoleh penghargaan berdasarkan budget emphasis, terlibat dan mempunyaipengaruh dalam penyusunan target anggaran (Brownell1982).

Sebagaimana yangdikemukakan Milani (1975), tingkat keterlibatan dan pengaruh bawahanterhadap pembuatan keputusan dalam proses penyusunan 
anggaran merupakan faktorutama yang membedakan antara anggaran partisipatif dengan anggaran nonpartisipatif.Aspirasi bawahan lebih diperhatikan dalam proses penyusunan anggaranpartisipatif, sehingga lebih memungkinkan bagi bawahan melakukan negosiasidengan atasan mengenai target anggaran yang menurut mereka dapat dicapai.

Leventhal (1980) serta Lind dan Tyler (1988) dalam Maiga dan Jacobs (2007) menyatakan bahwa keadilan prosedural berhubungan dengan pengaruh prosedur-prosedur pengambilan keputusan yang adil terhadap sikap dan perilaku orang-orang yang terlibat di dalam dan dipengaruhi oleh keputusan-keputusan mereka. Keadilan prosedural diakui mempunyai manfaat positif terhadap partisipasi para karyawan di dalam pengambilan keputusan (Lind dan Tyler 1988 dalam Maiga dan Jacobs 2007).

Dilihat dari sudut pandang penganggaran, keadilan prosedural merupakan persepsi bawahan atas keadilan proses yang digunakan oleh pimpinan (atasannya) untuk mengevaluasi kinerja bawahan, mengkomunikasikan umpan balik dari kinerja yang dicapai dan menentukan penghargaan bagi bawahan (Lau dan Lim, 2007 dalam Yucel dan Gunluk 2007). Pengaruh keadilan prosedural terhadap penganggaran partisipatif dapat dilihat dari meningkatnya inisiatif dan berbagi informasi antara atasan dan bawahan (Wang dan Nayir2010).

Sedangkan menurut pendapat Lindquist (1995) dalam Zainuddin dan Isa (2011) dengan adanya partisipasi memperbolehkan para bawahan untuk menyampaikan voice dan vote sehingga mereka dapat merasakan bahwa prosedurprosedur tersebut adil. Pada saat mereka mempunyai voice dan vote maka mereka akan merasa mempunyai keterlibatan yang tinggi atas pengendalian proses di dalam anggaran mereka.

Berdasarkan uraian tersebut maka hipotesis pertama dapat ditetapkan sebagai berikut.

H1: Keadilan prosedural berpengaruh positif terhadap penganggaran partisipatif.

Secara empiris penelitian Cropanzano dan Folger (1991) serta Kim dan Mauborgne (1993) dalam Lau dan Moser (2008) membuktikan adanya hubungan positif antara keadilan prosedural dengan komitmen organisasi. Bakshi et al.(2009) dalam Murtaza et al.(2011) juga menyatakan bahwa keadilan prosedural dan distributif secara signifikan berhubungan dengan komitmen organisasi karyawan di India, begitu pula hasil penelitian Lambert et al.(2005) dalam Murtaza et al.(2011) menyatakan bahwa keadilan prosedural dan distributif berhubungan positif signifikan dengan komitmen organisasi.

Clinton (1999) dalam Wong-On-Winget al. (2010) menyatakan bahwa komitmen organisasi merupakan anteseden dari penganggaran partisipatif. Hal ini 
diharapkan bahwa dengan adanya komitmen individu yang lebih kuat serta dengan keterlibatan mereka di dalam organisasi yang lebih tinggi maka dapat dicapai tingkat partisipasi dalam penyusunan anggaran yang lebih tinggi.

Komitmen organisasi mendorong manajer berpartisipasi dalam proses penganggaran. Kepercayaan yang kuat dari manajer terhadap dan diterimanya tujuan-tujuan dan nilai-nilai organisasi, mendorong manajer bersedia berpartisipasi dalam penyusunan anggaran. Manajer yang memiliki komitmen yang tinggi merasa memiliki organisasinya sehingga mau berpartisipasi dalam proses penyusunan anggaran. Komitmen organisasi mendorong partisipasi dalam penyusunan anggaran karena dengan partisipasi tersebut para manajer dapat mengusulkan kepada manajer atasannya mengenai usaha-usaha terbaik yang bermanfaat bagi organisasi dan dapat digunakan untuk mencapai tujuan organisasi yang dipimpinnya (Supriyono 2006).

Berdasarkan uraian tersebut maka hipotesis kedua dapat ditetapkan sebagai berikut.

H2: Keadilan prosedural berpengaruh positif terhadap penganggaran partisipatif melalui komitmen organisasi.

\section{Model Penelitian}

Berdasarkan hubungan antarvariabel maka dapat digambarkan model penelitian sebagai berikut.

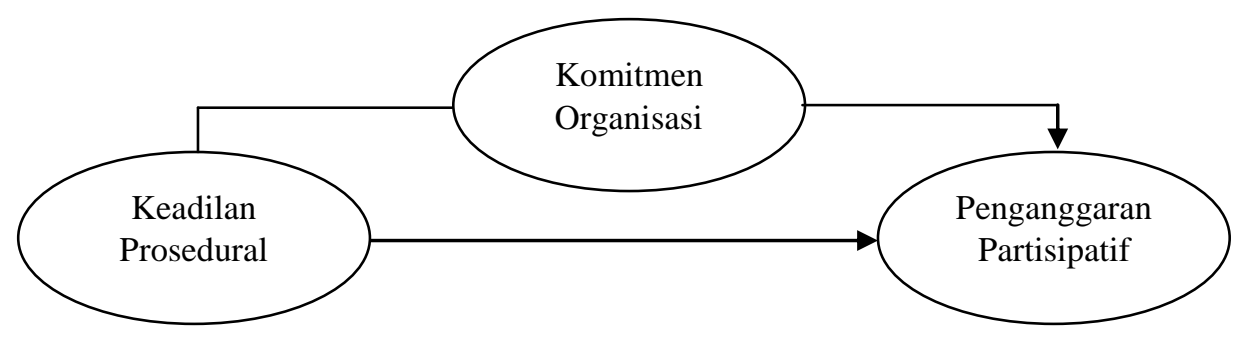

Gambar 1

Model Penelitian

\section{METODA PENELITIAN}

\section{Metoda Pengumpulan Data}

Dalam penelitian ini penulis melakukan berbagai teknik pengumpulan data yang bertujuan untuk mendapatkan data yang dibutuhkan dalam membuktikan hipotesis penelitian. Teknik pengumpulan data yang dilakukan penulis melalui: a) kuesioner tertutupberisi daftar pertanyaan yang disebarkan kepada responden aparatur pemerintahan daerah, dalam hal ini pejabat yang terlibat dalam penyusunan anggaran pada SKPD (eselon II, III dan IV) Pemprov Jawa Barat. Penyebaran kuesioner ini bertujuan untuk mendapatkan data langsung dari responden dengan 
harapan memperoleh data yang objektif dan b) wawancara,peneliti melakukan komunikasi langsung dengan para aparatur pemerintahan daerah yang terlibat dalam penyusunan anggaran pada SKPD Pemprov Jawa Barat. Wawancara ini dilakukan untuk mendapatkan informasi yang akurat dari para praktisi yang sangat berguna dalam menambah wawasan dan pengetahuan peneliti yang pada akhirnya akan berpengaruh pada hasil maupun kesimpulan penelitian.

\section{Populasi dan Sampel}

Populasi dalam penelitian ini adalah aparat pemerintah daerah pada 55 SKPD. Berdasarkan purposive sampling aparat yang menjadi sampel adalah sebanyak tiga responden dari setiap SKPD, yaitu sebanyak 165 responden, sebagai representasi dari eselon II, III dan IV yang terlibat langsung dalam penyusunan anggaran di setiap SKPD.Sebanyak 122 kuesioner dapat diterima kembali dari 165 kuesioner yang dibagikan.

\section{Operasionalisasi Variabel}

Variabel keadilan prosedural (Independen/X)diukur dengan menggunakan procedural fairness scale untuk menilai respon manajer, terdiri atas enam unsur yang dikembangkan oleh Magner dan Johnson (1995). Kemudian Maiga dan Jacobs (2007) berdasarkan ukuran yang digunakan oleh Leventhal (1980) memperbaharuinya dengan menambahkan dua unsur sehingga procedural fairness scale ini menjadi delapan unsur.

Komitmen organisasi (Intervening/Y)diukur dengan menggunakan instrumen yang disusun oleh Mowday et al.(1979) yang terdiri atas sembilan butir pertanyaan. Instrumen ini telah banyak digunakan secara luas dan divalidasi (telah teruji) diantaranya oleh: Nouri dan Parker (1996), Subramaniam dan Mia (2001), Supriyono (2005), Parker dan Kyj (2006), Yahya et al.(2008), serta Lau dan Moser (2008).

Variabel penganggaran partisipatif (Dependen/Z)diukur dengan menggunakan instrumen yang diperkenalkan oleh Milani (1975). Instrumen ini telah banyak digunakan secara luas dan divalidasi (telah teruji) dalam studi-studi akuntansi manajemen yang dilakukan oleh Brownell (1982), Brownell dan Hirst (1986), Chenhall dan Brownell (1988), Mia (1988), Brownell dan Dunk (1991), Harrison (1992), Lau et al. (1995), Nouri dan Parker (1998), Lau dan Buckland (2001), Wentzel (2002), Chong dan Chong (2002), Lau dan Tan (2006), serta Maiga dan Jacobs (2007).

\section{Metoda Analisis Data}

Data yang diperoleh dari para responden perlu diuji validitas dan reliabilitasnya untuk menghindari hal-hal yang dapat dan meragukan keabsahan penelitian ini, maka diperlukan pengujian-pengujian terhadap alat ukur tersebut. Uji validitas dan reliabilitas untuk memenuhi persyaratan utama yaitu: a) valid/sahih; b) reliabel/handal dan c) praktis (Cooper dan Schindler 2006). 
Untuk menganalisis data dalam penelitian ini digunakan Structural Equation Modeling (SEM) dengan bantuan Software Lisrel versi 8.7. Analisis ini digunakan untuk mengetahui besarnya pengaruh dari variabel independen terhadap variabel dependen serta dapat diketahui besarnya pengaruh variabel independen baik secara langsung maupun tidak langsung.

\section{HASIL ANALISIS}

\section{Hasil Pengujian Alat Ukur Penelitian}

Sebelum data hasil kuesioner penelitian dianalisis lebih lanjut, terlebih dahulu dilakukan uji validitas dan reliabilitas terhadap alat ukur penelitian untuk membuktikan apakah alat ukur yang digunakan memiliki kesahihan (validity) dan keandalan (reliability) untuk mengukur apa yang seharusnya menjadi fungsi ukurnya, yaitu untuk menguji apakah kuesioner telah mengukur secara cermat dan tepat apa yang ingin diukur pada penelitian ini.

Pengujian validitas menggunakan korelasi product moment (indeks validitas) dimana butir pernyataan dinyatakan valid jika koefisien korelasi butir pernyataan $\geq$ 0,30 (Kaplan-Saccuzzo 2005). Kemudian pengujian reliabilitas menggunakan metodaalpha-cronbach dan hasilnya dinyatakan reliabel jika koefisien reliabilitas lebih besar dari 0,70 (Kaplan-Saccuzzo 2005).

Tabel 2

Rangkuman Hasil Uji Validitas Kuesioner Penelitian

\begin{tabular}{lcl}
\hline \multicolumn{1}{c}{ Variabel } & $\begin{array}{c}\text { Kisaran Nilai Indeks } \\
\text { Validitas }\end{array}$ & Keterangan \\
\hline Keadilan Prosedural & $0,576-0,781$ & Semua Valid \\
Komitmen Organisasi & $0,503-0,702$ & Semua Valid \\
Penganggaran Partisipatif & $0,651-0,862$ & Semua Valid \\
\hline \multicolumn{2}{c}{ Sumber: Lampiran Output Uji Validitas dan Reliabilitas } &
\end{tabular}

Sumber: Lampiran Output Uji Validitas dan Reliabilitas

Rangkuman hasil pengujian validitas dan reliabilitas masing-masing kuesioner penelitian bisa dilihat pada Tabel 2.Berdasarkan hasil uji validitas seperti disajikan pada Tabel 2 dapat dilihat nilai terendah dari indeks validitas ketiga variabel lebih besar dari nilai kritis 0,30. Dengan demikian dapat disimpulkan bahwa seluruh item pernyataan yang digunakan untuk mengukur ketiga variabel sudah valid.

Tabel 3

Rangkuman Hasil Uji Reliabilitas Kuesioner Penelitian

\begin{tabular}{lcc}
\hline \multicolumn{1}{c}{ Variabel } & Koefisien Reliabilitas & Keterangan \\
\hline Keadilan Prosedural & 0,935 & Reliabel \\
Komitmen Organisasi & 0,926 & Reliabel \\
Penganggaran Partisipatif & 0,918 & Reliabel \\
\hline \multicolumn{2}{c}{ Sumber: Lampiran Output Uji Validitas dan Reliabilitas }
\end{tabular}


Pada Tabel 3 dapat dilihat nilai koefisien reliabilitas kuesioner ketiga variabel lebih besar dari 0,70,dengan demikian dapat disimpulkan bahwa kuesioner ketiga variabel sudah andal dan dapat digunakan untuk analisis selanjutnya.

\section{Analisis Deskriptif Data Hasil Kuesioner}

Gambaran data hasil penelitian dapat digunakan untuk memperkaya pembahasan, melalui gambaran data tanggapan responden dapat diketahui bagaimana tanggapan responden terhadap setiap indikator variabel yang sedang diteliti. Agar lebih mudah dalam menginterpretasikan variabel yang sedang diteliti, dilakukan kategorisasi terhadap skor tanggapan responden. Menurut Cooper dan Schindler (2006) untuk data ordinal atau data interval/ratio yang memiliki distribusi asimetris, ukuran pemusatan dapat dilakukan melalui distribusi rentang antarkuartil. Pada penelitian ini pengkategorisasian rata-rata skor tanggapan responden dilakukan menggunakan nilai kuartil dengan ketentuan sebagai berikut.

Skor minimum (1) - Kuartil I (2,5)

Kuartil I (2,5) - Kuartil II(4)

Kuartil II (4) - Kuartil III $(5,5)$

Kuartil III $(5,5)$ - Skor maksimum (7)
: Rendah/Buruk/Tidak pernah

: Kurang/Kadang-kadang

: Cukup/Sering

: Tinggi/Baik/Selalu

\section{Keadilan Prosedural}

Keadilan prosedural diukur menggunakan dua dimensidan dioperasionalisasikan menjadi 17 butir pernyataan.Berikut hasil kategorisasi rata-rata skor tanggapan responden terhadap masing-masing dimensi pada variabel keadilan prosedural.

Pada Tabel 4 dapat dilihat bahwa hasil perhitungan grand mean skor tanggapan responden mengenai keadilan prosedural sebesar 5,54 berada pada interval 5,5-7,0. Dengan demikian dapat disimpulkan bahwa keadilan prosedural menurut sebagian besar aparat SKPD pada Pemprov Jawa Barat sudah tinggi. Selanjutnya bila dilihat berdasarkan dimensi, rata-rata skor tanggapan responden terhadap dimensi formal budgetary procedures fairness termasuk dalam kategori tinggi, sedangkan rata-rata skor tanggapan responden terhadap dimensi budgetary procedures implementation fairness termasuk dalam kategori cukup.

Tabel 4

Rekapitulasi Mean Skor Jawaban Responden Mengenai Keadilan Prosedural

\begin{tabular}{clcc}
\hline No & \multicolumn{1}{c}{ Dimensi } & Mean Skor & Kriteria \\
\hline 1 & Formal budgetary procedures fairness & 5,75 & Tinggi \\
2 & Budgetary procedures implementation fairness & 5,25 & Tinggi \\
& Grand Mean & $\mathbf{5 , 5 4}$ & Tinggi \\
\hline
\end{tabular}

Sumber: Kuesioner diolah kembali 


\section{Komitmen Organisasi}

Komitmen organisasidiukur melalui tiga dimensi dan dioperasionalisasikan menjadi 20 butir pernyataan. Berikut rata-rata skor penilaian responden terhadap masing-masing dimensi pada variabel komitmen organisasi.

Tabel 5

Rekapitulasi Mean Skor Jawaban Responden Mengenai Komitmen Organisasi

\begin{tabular}{clcc}
\hline No & \multicolumn{1}{c}{ Dimensi } & Mean Skor & Kriteria \\
\hline 1 & Affective Commitment & 5,58 & Tinggi \\
2 & Continuance Commitment & 5,28 & Cukup \\
3 & Normative Commitment & 5,60 & Tinggi \\
& Grand Mean & $\mathbf{5 , 4 9}$ & Cukup \\
\hline
\end{tabular}

Sumber: Kuesioner diolah kembali

Pada Tabel 5 dapat dilihat bahwa hasil perhitungan grand mean skor tanggapan responden mengenai komitmen organisasi sebesar 5,49 berada pada interval 4-5,5. Dengan demikian dapat disimpulkan bahwa komitmen organisasi sebagian besaraparat SKPD pada PemprovJawa Barat cukup tinggi. Selanjutnya bila dilihat berdasarkan dimensi, rata-rata skor tanggapan responden terhadap dimensi continuance commitment termasuk dalam kategori cukup, sedangkan rata-rata skor tanggapan responden terhadap dimensi affective commitment dan normative commitment termasuk dalam kategori tinggi.

\section{Penganggaran Partisipatif}

Penganggaran partisipatifdiukur melalui dua dimensi dan dioperasionalisasikan menjadi tujuh butir pernyataan. Berikut rata-rata skor penilaian responden terhadap masing-masing dimensi pada variabel penganggaran partisipatif.

Pada Tabel 6 dapat dilihat bahwa hasil perhitungan grand mean skor tanggapan responden mengenai penganggaran partisipatif sebesar 6,05 berada pada interval 5,5-7,0. Dengan demikian dapat disimpulkan bahwa partisipasisebagian besaraparat SKPD pada PemprovJawa Barat sudah tinggi. Selanjutnya bila dilihat berdasarkan dimensi, rata-rata skor tanggapan responden terhadap dimensi tingkat partisipasi maupun pengaruh yang dirasakan termasuk dalam kategori tinggi.

Tabel 6

Rekapitulasi Mean Skor Jawaban Responden Mengenai Penganggaran Partisipatif

\begin{tabular}{clcc}
\hline No & \multicolumn{1}{c}{ Dimensi } & Mean Skor & Kriteria \\
\hline 1 & Tingkat partisipasi & 6,10 & Tinggi \\
2 & Pengaruh yang dirasakan & 5,98 & Tinggi \\
& Grand Mean & $\mathbf{6 , 0 5}$ & Tinggi \\
\hline
\end{tabular}

Sumber: Kuesioner diolah kembali 


\section{Pengujian Hipotesis}

Selanjutnya sesuai dengan tujuan penelitian, yaitu untuk menguji pengaruh dari keadilan prosedur(X) terhadap penganggaran partisipatif(Z)melalui komitmen organisasi (Y) maka penelitian ini melakukan serangkaian analisis kuantitatif yang relevan dengan tujuan penelitianmenggunakan SEM. Dalam SEMada dua jenis model yang terbentuk, yaitu model pengukuran dan model struktural.

Model pengukuran menjelaskan proporsi variance masing-masing variabel manifes (indikator) yang dapat dijelaskan di dalam variabel laten. Melalui model pengukuran akan diketahui indikator mana yang lebih dominan dalam merefleksikan variabel laten. Setelah model pengukuran masing-masing variabel laten diuraikan selanjutnya akan dijabarkan model struktural yang akan mengkaji pengaruh masingmasing variabel laten independen (exogenous latent variable) terhadap variabel laten dependen (endogenous latent variable).

\section{a. Hasil Uji Kecocokan Model}

Uji kecocokan model (goodness of fit) dilakukan untuk mengetahui apakah model yang diperoleh telah tepat dalam menggambarkan hubungan antarvariabel yang sedang diteliti sehingga dapat dikategorikan kedalam model yang baik. Uji kecocokan model dalam SEMdapat dilihat berdasarkan beberapa kriteria pengujian kecocokan model seperti disajikan pada tabel berikut.

Tabel 7

Hasil Uji kecocokan Model

\begin{tabular}{lc}
\hline Ukuran Goodness of Fit & Nilai Hasil Estimasi \\
\hline Chi-Square & $300,9$ (p-value $=0,002)$ \\
$R M S E A$ & $0,055^{*}$ \\
$G F I$ & 0,822 \\
$A G F I$ & 0,777 \\
$R M R$ & $0,068^{*}$ \\
$S R M R$ & $0,068^{*}$ \\
NFI & $0,937^{*}$ \\
$C F I$ & $0,976^{*}$ \\
$I F I$ & $0,976^{*}$ \\
$R F I$ & $0,927^{*}$ \\
\hline
\end{tabular}

*memenuhi kriteria model yang baik

Berikut penjelasan dari masing-masing uji kecocokan model tersebut.

1. Hasil pengujian kecocokan menggunakan uji $\chi^{2}$ (chi-square) untuk model yang diteliti diperoleh nilai sebesar 300,9 dengan $p$-value $=0,002$. Menurut Hair et al. (2006) dalam SEM tidak diinginkan p-value yang kecil (secara statistik signifikan). Kembali pada hasil diatas dapat dilihat $p$-value lebih kecil dari 0,05 menunjukkan bahwa uji $\chi^{2}$ signifikan. Jadi bila mengacu pada hasil uji $\chi^{2}$ maka model yang diperoleh belum memenuhi kriteria. Namun masih menurut Hair et al. 
(2006), sulitnya mendapatkan $p$-value lebih besar dari 0,05 pada uji $\chi^{2}$ maka dikembangkan beberapa ukuran kecocokan model lainnya.

2. RMSEA(Root Mean Square Error of Approximation), ukuran lainya yang masih memiliki hubungan dengan uji $\chi^{2}$ adalah RMSEA. Berapa nilai RMSEA yang baik masih diperdebatkan, namun menurut Hair et al. (2006) bila nilai RMSEA dibawah 0,08 model masih bisa diterima.

3. Dilihat dari nilai GFI(Goodness of Fit Index)untuk model yang diteliti sebesar 0,822 menunjukkan model yang diperoleh belum memenuhi kriteria,di mana menurut Hair et al. (2006)nilai GFI lebih besar dari 0,90 menunjukkan model yang baik.

4. RMR(Root Mean Square Residual) pada model yang diteliti sebesar 0,068, demikian juga nilai standarisasinya (SRMR) sebesar 0,068. Menurut Hair et al. (2006) nilai StandardizedRoot Mean Square Residual(SRMR) kurang dari 0,08 memenuhi kriteria model yang baik.

Hasil ukuran kesesuaian absolut menunjukkan model yang diperoleh memenuhi kriteria goodness of fit pada ukuran RMSEA $(0,055<0,08)$ dan SRMR $(0,068<0,080)$ sehingga dapat disimpulkan bahwa model hasil estimasi dapat diterima, artinya model empiris yang diperoleh masih sesuai dengan model teoritis.

\section{b. Model Pengukuran}

Model pengukuran merupakan model yang menghubungkan antara variabel laten dengan variabel manifes. Pada penelitian ini terdapat sepuluh variabel laten dengan jumlah variabel manifes sebanyak 23. Variabel laten keadilan prosedur terdiri atas sembilan variabel manifes, komitmen organisasi terdiri atas sembilan variabel manifes danpenganggaran partisipatif terdiri atas lima variabel manifes.

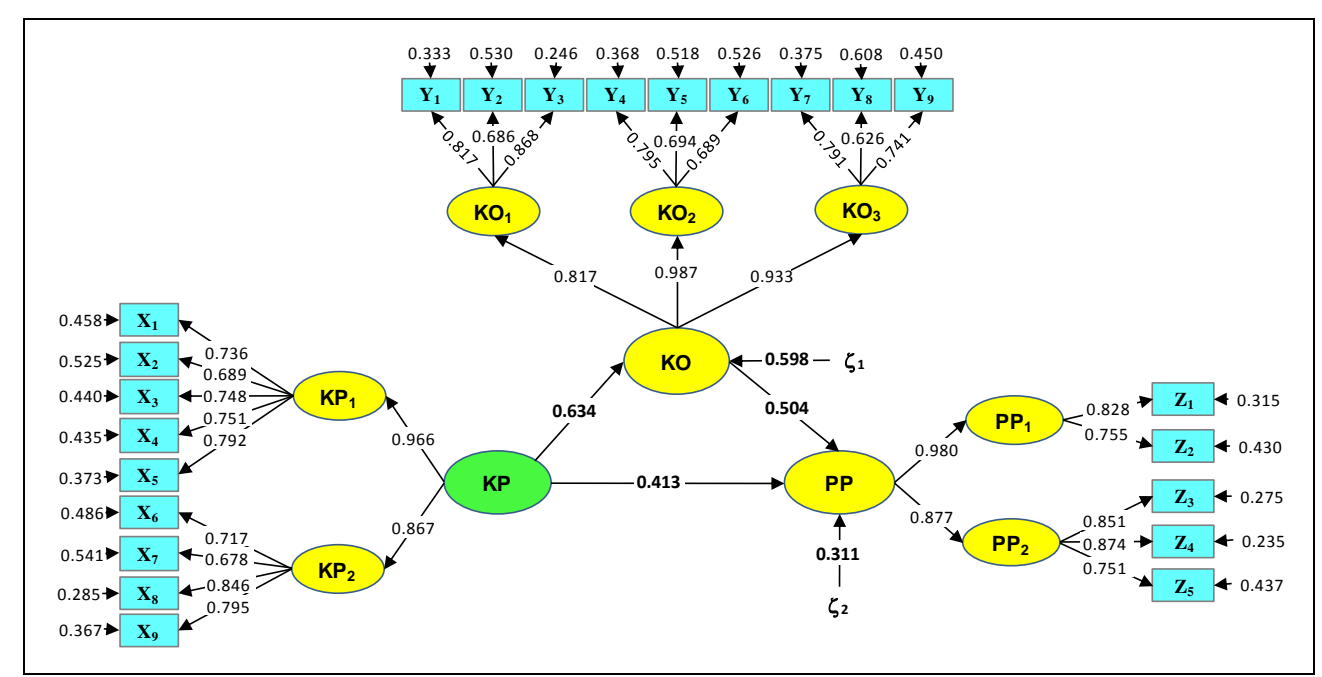

Sumber : Hasil pengolahan Lisrel versi 8.7

Gambar 2

Koefisien Standarisasi Permodelan Persamaan Struktural 
Pada uji kecocokan model (goodness of fit) menyimpulkan bahwa model dapat diterima, artinya model yang diperoleh dapat digunakan untuk menguji hipotesis penelitian yang telah diajukan. Menggunakan metoda estimasi maximum likelihood diperoleh diagram jalur full modelpengaruh keadilan prosedur terhadap penganggaran partisipatifmelalui komitmen organisasiseperti pada Gambar 2.

Melalui bobot faktor yang terdapat pada Gambar 2 dapat dilihat pada variabel laten keadilan prosedur (KP), dimensi $\mathrm{KP}_{1}$ (formal budgetary procedures fairness) lebih kuat dalam mencerminkan variabel laten keadilan prosedurdibanding $\mathrm{KP}_{2}$ (budgetary procedures implementation fairness). Selanjutnya pada variabel laten komitmen organisasi $(\mathrm{KO})$, dimensi $\mathrm{KO}_{2}$ (continuance Commitment)paling kuat dalam mencerminkanvariabel laten komitmen organisasi, kemudian disusul dimensi $\mathrm{KO}_{3}$ (normative commitment). Sedangkan dimensi $\mathrm{KO}_{1}$ (affective commitment) paling lemah dalam mencerminkanvariabel laten komitmen organisasi. Terakhir pada variabel laten penganggaran partisipatif $(\mathrm{PP})$, dimensi $\mathrm{PP}_{1}$ (tingkat partisipasi) lebih kuat dalam mencerminkan variabel laten penganggaran partisipatifdibanding $\mathrm{PP}_{2}$ (pengaruh yang dirasakan).

Selanjutnya dilakukan pengujian apakah indikator-indikator yang digunakan untuk mengukur keadilan prosedur, komitmen organisasi danpenganggaran partisipatifmemiliki derajat kesesuaian yang tinggi melalui pendekatan construct reliability dan variance extracted. Hasil pengujian untuk masing masing indikator variabel laten diuraikan pada tabel berikut.

Tabel 8

Construct Reliability dan Variance Extracted

Model Pengukuran Masing-Masing Variabel

\begin{tabular}{lccccc}
\hline \multirow{2}{*}{ Variabel } & \multirow{2}{*}{ Dimensi } & \multicolumn{2}{c}{ First Order } & \multicolumn{2}{c}{ Second Order } \\
& & $\boldsymbol{C R}$ & $\boldsymbol{V E}$ & $\boldsymbol{C R}$ & $\boldsymbol{V} \boldsymbol{2}$ \\
\hline Keadilan & $\mathrm{KP}_{1}$ & 0,861 & 0,553 & \multirow{2}{*}{0,914} & 0,842 \\
Prosedural & $\mathrm{KP}_{2}$ & 0,846 & 0,580 & & \\
Komitmen & $\mathrm{KO}_{1}$ & 0,835 & 0,631 & & \\
Organisasi & $\mathrm{KO}_{2}$ & 0,771 & 0,529 & 0,939 & 0,837 \\
& $\mathrm{KO}_{3}$ & 0,765 & 0,522 & & \\
Penganggaran & $\mathrm{PP}_{1}$ & 0,771 & 0,628 & \multirow{2}{*}{0,927} & 0,865 \\
Partisipatif & $\mathrm{PP}_{2}$ & 0,866 & 0,684 & &
\end{tabular}

Sumber: Hasil pengolahan Lisrel versi 8.7

Berdasarkan hasil order pertama dari confirmatory factor analysis dapat dilihat nilai Composite Reliability (CR) masing-masing dimensi lebih besar dari 0,70 yang menunjukkan bahwa indikator memiliki kekonsistenan dalam mengukur dimensinya masing-masing. Selanjutnya nilai AverageVariance Extracted(AVE) masing-masing dimensi lebih besar dari 0,50 menunjukkan bahwa secara rata-rata lebih dari 50 persen informasi yang terdapat pada masing-masing indikator bisa tercermin melalui dimensinya. 
Kemudian berdasarkan hasil order kedua dari confirmatory factor analysis dapat dilihat nilai Composite Reliability (CR) masing-masing variabel lebih besar dari 0,70 yang menunjukkan bahwa dimensi memiliki kekonsistenan dalam mengukur variabelnya masing-masing. Selanjutnya nilai Average Variance Extracted(AVE) masing-masing variabel lebih besar dari 0,50 menunjukkan bahwa secara rata-rata lebih dari 50 persen informasi yang terdapat pada masing-masing dimensi bisa tercermin melalui variabelnya.

\section{c. Model Struktural}

Model struktural adalah model yang menghubungkan variabel laten exogenous dengan variabel laten endogenous atau hubungan variabel endogenous dengan variabel endogenous lainnya. Berikut rangkuman nilai-nilai yang digunakan dalam model struktural.

Tabel 9

Rangkuman Hasil Uji Statistik

\begin{tabular}{clccc}
\hline Sub Struktur & Jalur & Koefisien Jalur & $\mathbf{t}_{\text {hitung }}$ * & R-Square \\
\hline Pertama & $\mathrm{KP} \rightarrow \mathrm{KO}$ & 0,634 & 5,353 & 0,402 \\
Kedua & $\mathrm{KP} \rightarrow \mathrm{PP}$ & 0,413 & 3,347 & 0,689 \\
& $\mathrm{KO} \rightarrow \mathrm{PP}$ & 0,504 & 3,790 & \\
\hline
\end{tabular}

$* \mathrm{t}_{\mathrm{kritis}}=1,96$

Sumber: Hasil pengolahan Lisrel versi 8.7

Melalui nilai $R$-square dapat diketahui bahwa keadilan prosedur (KP) secara parsial memberikan pengaruh sebesar 40,2 persen terhadap komitmen organisasi (KO) dan sisanya sebesar 59,8persen merupakan pengaruhfaktor-faktor lain yang tidak diteliti.Kemudian keadilan prosedur (KP) dan komitmen organisasi (KO) secara bersama-sama memberikan pengaruh sebesar 68,9persen terhadap penganggaran partisipatif (PP), sedangkan sisanya sebesar 31,1persen merupakan pengaruh faktor-faktor lain yang tidak diteliti.

Selanjutnya dilakukan pengujian hipotesis untuk membuktikan ada tidaknya pengaruh keadilan prosedur terhadap penganggaran partisipatifmelalui komitmen organisasi.

\section{Pengaruh Keadilan Prosedural Terhadap Penganggaran partisipatif}

Hasil pengujian statistik pengaruh keadilan procedural terhadap penganggaran partisipatif dapat dilihat pada tabel berikut.

Tabel 10

Hasil Pengujian Pengaruh Keadilan Prosedural terhadap Penganggaran partisipatif

\begin{tabular}{ccccc}
\hline Koef. Jalur & $\mathbf{t}_{\text {hitung }}$ & $\mathbf{t}_{\text {kritis }}$ & Ho & Ha \\
\hline 0,413 & 3,347 & 1,96 & Ditolak & diterima \\
\hline
\end{tabular}

Sumber: Hasil pengolahan Lisrel versi 8.7 
Berdasarkan hasil pengujian dapat dilihat nilai $t_{\text {hitung }}$ variabel keadilan prosedural $(3,347)$ lebih besar dari $t_{\text {kritis }}(1,96)$. Karena nilai $t_{\text {hitung }}$ lebih besar dibanding $\mathrm{t}_{\text {kritis, }}$, maka pada tingkat kekeliruan limapersen diputuskan untuk menolak Ho sehingga Ha diterima. Jadi berdasarkan hasil pengujian dapat disimpulkan bahwa keadilan prosedural secara parsial berpengaruh positif terhadap penganggaran partisipatifaparat SKPD di PemprovJawa Barat. Secara langsung keadilan prosedural memberikan kontribusi sebesar 17,1persen terhadap penganggaran partisipatifaparat SKPD di PemprovJawa Barat.

\section{Pengaruh Keadilan Proseduralterhadap Penganggaran Partisipatif Melalui Komitmen Organisasi}

Selanjutnya untuk menguji pengaruhkeadilan proseduralterhadappenganggaranpartisipatifmelalui komitmen organisasisebagai variabel intervening digunakan Sobel test (Kline 2011), yaitu dengan mengalikan koefisien dari masing-masing jalur.

Tabel 11

Hasil UjiPengaruh Keadilan Prosedural terhadap Penganggaran Partisipatif Melalui Komitmen Organisasi

\begin{tabular}{ccccc}
\hline Pengaruh tidak langsung & $\mathbf{t}_{\text {hitung }}$ & $\mathbf{t}_{\text {kritis }}$ & Ho & Ha \\
\hline $0,634 \times 0,413 \times 0,504$ & 3,097 & 1,96 & ditolak & Diterima \\
\hline Sumber: Hasil pengolahan Lisrel versi 8.7 & & &
\end{tabular}

Berdasarkan hasil pengujian dapat dilihat nilai $t_{\text {hitung }}$ pengaruhkeadilan proseduralterhadappenganggaran partisipatif melalui komitmen organisasi $(3,079)$ lebih besar dari $t_{\text {kritis }}(1,96)$. Karena nilai $t_{\text {hitung }}$ lebih besar dibanding $t_{\text {tabel }}$, maka dengan tingkat kekeliruan limapersen diputuskan untuk menolak Ho sehingga $\mathrm{Ha}$ diterima. Jadi berdasarkan hasil pengujian dapat disimpulkan bahwa keadilan proseduralberpengaruh positif terhadappenganggaran partisipatifmelaluikomitmen organisasi. Dengan kata lain secara tidak langsung melalui komitmen organisasi, keadilan prosedural memberikan pengaruh sebesar 13,2persen terhadap penganggaran partisipatif.

\section{PEMBAHASAN}

Keadilan prosedural merupakan sisi keadilan dalam penganggaran yang memperhatikan aspek prosedur yang digunakan dalam melakukan distribusi anggaran. Berdasarkan hasil penelitian menunjukkan bahwa keadilan prosedural melalui dimensi formal budgetary procedures fairness yang ditunjukkan oleh adanya kesempatan untuk menyampaikan pendapat dalam hubungannya dengan keputusan penganggaran, ketentuan yang memperbolehkan aparat dalam mempertimbangkan keputusan anggaran, keputusan anggaran mempengaruhi program atas dasar informasi yang akurat, konsistensi dalam menerapkan prosedur penganggaran dan 
kesesuaian prosedur penganggaran dengan etika dan moral, lebih banyak direfleksikan oleh adanya kesesuaian prosedur penganggaran dengan etika dan moral.

Sedangkan budgetary procedures implementation fairness yang ditunjukkan oleh adanya kepedulian, perhatian dan rasa hormat dalam menerapkan prosedur penganggaran, adanya pertimbangan yang sungguh-sungguh atas pendapat yang disampaikan dalam penyusunan anggaran, adanya penjelasan yang mencukupi, jelas dan tepat waktu, serta menghindari bias antarunit dalam menerapkan prosedur anggaran lebih banyak direfleksikan oleh adanya penjelasan yang mencukupi, jelas dan tepat waktu dalam menerapkan prosedur penganggaran.

Hasil penelitian juga menunjukkan bahwa formal budgetary procedures fairness dan budgetary procedures implementation fairness dalam kategori tinggi. Formal budgetary procedures fairness lebih merefleksikan keadilan prosedural. Artinya bahwa aparat SKPD telah memahami adanya prosedur dalam penyusunan anggaran dan prosedur penganggaran tersebut telah dirasakan adil dalam hubungannya dengan distribusi anggaran untuk masing-masing wilayah tanggung jawabnya.

Hasil pengujian hipotesis menunjukkan bahwa keadilan prosedural mempengaruhi penganggaran partisipatif, dengan adanya keadilan prosedural yang tinggi maka dapat meningkatkan penganggaran partisipatif aparat SKPD PemprovJawa Barat. Hal ini sejalan dengan hasil penelitian yang telah dilakukan oleh Leventhal (1980) serta Lind dan Tyler (1988) dalam Maiga dan Jacobs (2007), Lau dan Lim (2002) dalam Yucel dan Gunluk (2007), Wang dan Nayir (2010) dan Linquist (1995) dalam Zainuddin dan Isa (2011) artinya bahwa keadilan prosedural berhubungan dengan pengaruh prosedur-prosedur pengambilan keputusan yang adil terhadap sikap dan perilaku aparat SKPD yang terlibat di dalam dan dipengaruhi oleh keputusan-keputusan mereka yang berhubungan dengan penyusunan anggaran. Keadilan prosedural mempunyai manfaat yang baik (positif) terhadap partisipasi aparat SKPD dalam pengambilan keputusan anggaran hal ini dapat dilihat dari meningkatnya inisiatif dan berbagi informasi antara atasan dan bawahan.

Selanjutnya berdasarkan hasil pengujian statistik menunjukkan bahwa komitmen afektifdan komitmen normatif mempunyai skor yang tinggi sedangkan komitmen berkelanjutan(continuance) mempunyai skor cukup. Komitmen berkelanjutan lebih merefleksikan komitmen organisasi dengan maksud bahwa aparat yang memiliki komitmen berkelanjutan yang tinggi tetap menjadi anggota organisasi karena pertimbangan kebutuhan untuk tetap menjadi anggota organisasi tersebut.

Secara normatif seharusnya aparat PNS memiliki komitmen afektif. Aparat dengan komitmen afektif yang tinggi menunjukkan adanya keterkaitan emosional dan keterlibatan yang tinggi dalam mencapai tujuan organisasi. Namun, bukti 
empiris menunjukkan ternyata bentuk komitmen organisasi aparat SKPD masih bersifat komitmen berkelanjutan, artinya adanya pertimbangan untung rugi jika tetap bertahan atau meninggalkan organisasi tempatnya bekerja di mana status sebagai PNS merupakan dambaan bagi mereka.Sesuai dengan hasil wawancara menunjukkan bahwa aparat bekerja pada SKPD karena memang sudah menjadi tugasnya dan akan tetap bertahan dalam lingkungan SKPD meskipun sangat terbuka kemungkinan terjadinya mutasi/rotasi ke SKPD lain sebagai bentuk penugasan yang harus mereka terima.

Hasil pengujian hipotesis menunjukkan bahwa komitmen organisasi mempengaruhi penganggaran partisipatif, dengan adanya komitmen organisasi yang tinggi maka dapat meningkatkan penganggaran partisipatif aparat SKPD PemprovJawa Barat. Hal ini sejalan dengan hasil penelitian yang telah dilakukan Bakshi et al.(2009) dalam Murtaza et al.(2011) juga menyatakan bahwa keadilan prosedural dan distributif secara signifikan berhubungan dengan komitmen organisasi karyawan di India, begitu pula hasil penelitian Lambert et al.(2005) dalam Murtaza et al.(2011) menyatakan bahwa keadilan prosedural dan distributif berhubungan positif signifikan dengan komitmen organisasi, serta Supriyono (2006) dan Clinton (1999) dalam Wong-On-Winget al. (2010) yang menyatakan bahwa komitmen organisasi mempengaruhi penganggaran partisipatif. Artinya, dengan adanya prosedur penyusunan anggaran yang adil dan ditunjang dengan adanya komitmen dari individu (dalam hal ini adalah aparat SKPD) yang lebih kuat/tinggi serta keterlibatan aparat di dalam organisasi yang lebih tinggi dapat dicapai tingkat partisipasi aparat dalam penyusunan anggaran yang lebih tinggi pula.

\section{SIMPULAN DAN REKOMENDASI}

\section{Simpulan}

Keadilan prosedural secara langsung berpengaruh positif terhadap penganggaran partisipatif begitu pula keadilan prosedural secara tidak langsung melalui komitmen organisasi berpengaruh terhadap penganggaran partisipatif.Hal ini berarti bahwa keadilan prosedural berhubungan dengan pengaruh prosedur-prosedur pengambilan keputusan yang adil terhadap sikap dan perilaku aparat SKPD yang terlibat di dalam dan dipengaruhi oleh keputusan-keputusan mereka yang berhubungan dengan penyusunan anggaran yang sesuai dengan bidang tanggung jawabnya. Keadilan prosedural mempunyai manfaat positif terhadap partisipasi aparat SKPD dalam pengambilan keputusan anggaran hal ini dapat dilihat dari meningkatnya inisiatif dan berbagi informasi antara atasan dan bawahan.Pada akhirnya dengan prosedur penyusunan anggaran yang adil dan ditunjang dengan adanya komitmen aparat SKPD yang lebih kuat/tinggi serta keterlibatan aparat SKPD di dalam organisasi yang lebih tinggi dapat dicapai tingkat partisipasi aparat dalam penyusunan anggaran yang lebih tinggi pula. 


\section{Rekomendasi}

1. Keadilan dalam pelaksanaan prosedur penganggaran dapat lebih baik lagi, jika pimpinan dapat memberikan perhatian yang lebih, memberikan pertimbangan yang sungguh-sungguh dan memberikan penjelasan yang lebih baik pada saat bawahan menerapkan standar operasional prosedur dalam penyusunan anggaran.

2. Pimpinan tidak hanya memberikan penugasan sesuai dengan Tupoksinya (Tugas Pokok dan Fungsi) akan tetapi dapat juga memberikan penugasan di luar Tupoksinya dalam lingkungan SKPD yang bersangkutan sehingga dapat lebih meningkatkan jalinan emosional antara aparat dengan organisasinya, agar dapat tercapai komitmen aparat SKPD terhadap organisasinya sesuai dengan yang diharapkan (affective commitment).

3. Tingkat partisipasi dalam penyusunan anggaran dapat lebih ditingkatkan lagi, apabila pimpinan dapat lebih melibatkan bawahannya baik dalam hal penyusunan program, kegiatan, maupun anggaran sehingga para bawahan menilai bahwa mereka telah memberikan kontribusi yang besar dalam penyusunan anggaran SKPD.

\section{DAFTAR PUSTAKA}

Allen, N.J., dan J. P. Meyer. 1990. The measurement and antecedents of affective, continuance and normative commitment to organization.Journal of Occupational Psychology. Vol.63: 1-18.

Aquino, K., M. U. Lewis, dan M. Bradfield. 1999.Justice constructs, negative affectivity, and employee deviance: A proposed model and empirical test.Journal of Organizational Behavior. Vol.20: 1073-1091.

Brownell, P. 1982. The role of accounting data in performance evaluation, budgetary participative and organizational effectiveness.Journal of Accounting Research. Vol.20 (Spring): 12-27.

and M.Hirst. 1986. Reliance on accounting information, budgetary participation, and task uncertainty: Tests of a three-way interaction.Journal of Accounting Research. Vol.24 No.2: 241-249.

and M. McInnes. 1986. Budgetary participation, motivation, and managerial performance.The Accounting Review. Vol.56 No.4: 587- 600.

and A. Dunk. 1991. Task uncertainty and its interaction with budgetary participation and budget emphasis: Some methodological issues and empirical investigation. Accounting, Organizations, and Society. Vol.16: 693-703. 
Bryan, J. F., dan E. A. Locke. 1967. Goal setting as a means of increasing motivation. Journal of Applied Psychology. Vol.53 No.3: 274-277.

Campbell, D. J., dan K. F. Gingrich. 1986. The interactive effects of task compexity and participation on task performance: A field experiment.Organizational Behavior and Human Decision Processes: 162-180.

Chenhall, R. H., dan P. Brownell. 1988. The effect participative budgeting on job satisfaction and performance: Role ambiguity as an intervening variable.Accounting, Organization, and Society. Vol.13 No.3: 225-233.

Chong, V. K., dan K. M. Chong. 2002. Budget goal commitment and informational effects of budget participation on performance: A structural equation modeling approach. Behavioral Research In Accounting. Vol.14.

Cherrington, D. J., dan J. O. Cherrington. 1973. Appropriate reinforcement contigencies in the budgeting process.Journal of Accounting Research (supplemen):225-253.

Conlon, D. E. 1993. Some tests of the self-interest and group-value models of procedural justice: Evidence from an organizational appeal procedure. Academy of Management Journal. Vol.36: 1109-1124.

Cooper, D. R., dan P. S. Schindler. 2006. Business Research Methods. Ninth Edition. International Edition. Mc Graw Hill.

Cropanzano, R., dan R. Folger. 1991. Procedural Justice And Worker Motivation. In R. M. Steers \& L. W. Porter (Eds.). Motivation And Work Behavior5th Ed. New York: McGraw-Hill.

Dellaportas, S., K. Gibson, R. Alagiah, M. Hutchinson, P. Leung, dan D. V. Homrigh. 2005. Ethics, Governance \& Accountability A Professional Perspective. John Willey \& Sons Australia Ltd.

Dossett, D.L., G. P. Latham, dan T. R. Mitchell. 1979. The effects of assigned versus participatively set goals, KR, and individual differences when goal difficulty is held constant. Journal of Applied Psychology. Vol.64: 291-298.

Hope, J., dan R. Fraser. 2003. Beyond Budgeting: How Managers Can Break Free from the Annual Performance Trap. Harvard Business School Press. Boston. Massachusetts.

Fryxell, G. E.1992. Perceptions of justice afforded by formal grievance systems as predictors of a belief in a just workplace.Journal of Business Ethics. Vol.11 No.8: 635-647.

Greenberg, J. 1986. Determinants of perceived fairness of performance evaluations. Journal of Applied Psychology. Vol.71: 340-342. 
Hair, J.F., W. C. Anderson, B. J. Black, R. E. Babin, Anderson, dan L. R. Tatham. 2006. Multivariate Data Analysis. Sixth Edition. Pearson Education International.

Harrison, G. L. 1992. The cross-culturally generalizability of the relation between participation, budget emphasis and job-related attitudes.Accounting, Organization, and Society. Vol.17 No.1: 1-15.

Ivancevich, J. 1976. The effects of goal setting on performance and job satisfaction. Journal Of Applied Psychology(October): 605-612.

Kaplan, R. M., dan D. P Saccuzo. 2005. Psychological Testing, Principles, Aplications, and Issues. SixthEdition. Thomson Wadsworth, Belmont USA.

Kenis, I. 1979. Effect of budgetary goal characteristics on managerial attitudes and performance. The Accounting Review. Vol.54: 707-721.

Kinnersley, R. L., dan N. R. Magner. 2008. Fair governmental budgetary procedures: Insights from past research and implications for the future. Journal of Public Budgeting, Accounting, and Financial Management. Vol.20 No.3: 355-374.

Kline, R. B. 2011. Principles and Practices of Structural Equation Modeling. New York: Third Edition.The Guilford Press.

Latham, G. P., dan L. M. Saari. 1979. The effects of holding goal difficulty constant on assigned and participatively set goals. Academy of Management Journal. Vol.22: 163-168.

Lau, C. M., dan E. Lim. 2002. TheIntervening effects of participation on the relationship between procedural justice and managerial performance. The British Accounting Review. Vol.34: 55-78.

dan S. L. C. Tan. 2006. The effect of procedural fairness and interpersonal trust on job tension in budgeting. Managerial Accounting Research: 171186.

dan A. Moser. 2008. Behavioral effects of non financial performance measures: The role of procedural fairness. Behavioral Research in Accounting. Vol.20 No.2: 55-71.

Levanthal, G. S. 1980. What should be done with equity theory? New approaches to the study of fairness in social relationships. Social Exchange: Advances in Theory and Research: 27-55.

Libby, T. 1999. The influence of voice and explanation on performance in a participative budgeting setting.Accounting Organization and Society. Vol.24 No.2: 125-137.

Locke, E.A. 1984. Goal Setting: A Motivational Technique that Works! Englewood Cliffs.NJ. Prentice-Hall. 
Magner, N. R., dan G. G. Johnson. 1995. Municipal officials reactions to justice in budgetary resource allocation. Public Administrative Quarterly. Vol.18 No.4: 439-456.

Maiga, A. S.,dan F. A. Jacobs. 2007. Budget participation's influence on budget slack: The role of fairness perceptions, trust, and goal commitment. Journal Accounting Management Research. Vol.5 No.1.

Merchant, K. A. 1981. The design of the corporate budgeting system: Influences on managerial behavior and performance. The Accounting Review. (October): 813-829.

Milani, K. W. 1975. The relationship of participation in budget-setting to industrial supervisor performance and attitudes: A Field Study. The Accounting Review: 274-285.

Mowday, R. T. 1979. The measurement of organizational commitment. Journal of Vocational Behaviour. Vol.14: 224-247.

Murtaza, G., I. Shad., K. Shahzad., M. K. Shah, dan A. K. Nadeem. 2011. Impact of distributive and procedural justice on employee's commitment: A case of public organization of Pakistan. European Journal of Economics, Finance, and Administrative Sciences. Vol.29: 73-80.

Nouri, H., dan R. J. Parker. 1998. The relationship between budget participation and job performance: The roles of budget adequacy and organizational commitment.Accounting, Organization, and Society. Vol.23: 467-483.

Parker, R. J., dan L.Kyj. 2006. Vertical information sharing in the budgeting process. Accounting, Organization, and Society. Vol.31:27-45.

Robbins, S. R., dan T. A. Judge. 2008. Perilaku Organisasional. Jakarta: Penerbit Salemba Empat.

Shields, J. F., dan M. D. Shields. 1998. Antecedents of participate budgeting. Accounting, Organization, and Society. Vol.23 No.1: 49-76.

Siegel, G., dan H. K. Marconi. 1989. Behavioral Accounting. South-Western Publishing Co. Cincinnati.

Sopiah. 2008. Perilaku Organisasional. Yogyakarta: Penerbit Andi.

Staley, A. B., dan N. R. Magner. 2007. Budgetary fairness, supervisory trust, and the propensity to create budgetary slack: Testing a social exchange model in a government budgeting context. Advances in Accounting Behavioral Research. Vol.10: 159-182.

Stedry, G.1960.Budget Control and Cost Behavior. Englewood Cliff, N.J: Prentice Hall.Inc. 
Subramaniam, N., dan L. Mia. 2001. The relation between decentralised structure, budgetary participation and organisational commitment the moderating role of managers value orientation towards innovation. Accounting, Auditing \& Accountability Journal. Vol.14. No.1: 12-29.

Suharman, H. 2006. Pengaruh budget emphasis terhadap kinerja manajerial. Jurnal Bisnis, Manajemen, dan Ekonomi. Vol.7 No. 3(Februari).

Supriyono, R. A. 2006. Pengaruh variabel perantara komitmen organisasi dan partisipasi penganggaran terhadap hubungan antara usia dan kinerja manajer di Indonesia. Jurnal Ekonomi dan Bisnis. Vol.1 (Februari): 31-45.

Tyler, T. R., dan S. L. Blader. 2003. The group engagement model: Procedural justice, social identity, and cooperative behavior. Personality and Social Psychology Review. Vol.7 No.4: 349-361.

Wang, K. Y., dan D. Z. Nayir. 2010. Procedural justice, participation, and power distance: Information sharing in Chinese firms. Available at www.emeraldinsight.com.

Wentzel, K. 2002. The influence of fairness perceptions and goal commitment on managers' performance in a budget setting. Behavioral Research In Accounting. Vol.14.

Wong-On-Wing, B., L. Guo, dan G. Lui. 2010. Intrinsic and extrinsic motivation and participation in budgeting: Antecedents and concequences. Behavioral Research in Accounting. Vol.22. No.2: 133-153.

Yahya, M., N. N. N. Ahmad, dan A. H. Fatima. 2008. Budgetary participation and performance: Some Malaysian evidence. International Journal of Public Management. Vol.21 No.6: 658-673.

Yucel, R., dan M. Gunluk. 2007. Effect of budgetary control and justice perceptions on the relationship between budgetary particpation and performance. Journal of Global Strategic Management. (October): 82-93.

Zainuddin, S., dan C. R. Isa. 2011. The role of procedural fairness in the relationship between budget participation and motivation. Australian Journal of Basic and Applied Sciences. Vol.5 No.9: 1.464-1.473. 